\title{
Manifestation of Spontaneous and Early Autoimmune Gastritis in CCR7-Deficient Mice
}

\author{
Susann Winter, ${ }^{*}$ Armin Rehm, ${ }^{\dagger \neq}$ \\ Katharina Wichner, ${ }^{*}$ Tobias Scheel, ${ }^{\S}$ \\ Arvind Batra, " Britta Siegmund, " Claudia Berek, \\ Martin Lipp, * and Uta E. Höpken* \\ From the Departments of Tumor Genetics and Immunogenetics, ${ }^{*}$ and \\ Hematology, Oncology and Tumor Immunology, ${ }^{\dagger}$ Max-Delbrück- \\ Center for Molecular Medicine, Berlin; the Departments of \\ Hematology and Oncology ${ }^{*}$ and Medicine I, "Charité Medical \\ University, Berlin; and the Deutsches Rheuma-Forschungszentrum \\ Berlin, ${ }^{\S}$ Leibniz Institute, Berlin, Germany
}

Autoimmune gastritis is a common autoimmune disorder characterized by chronic inflammatory cell infiltrates, atrophy of the corpus and fundus, and the occurrence of autoantibodies to parietal cell antigen. In CCR7-deficient mice, autoimmune gastritis developed spontaneously and was accompanied by metaplasia of the gastric mucosa and by the formation of tertiary lymphoid organs at gastric mucosal sites. $T$ cells of CCR7-deficient mice showed an activated phenotype in the gastric mucosa, mesenteric lymph nodes, and peripheral blood. In addition, elevated serum IgG levels specific to gastric parietal cell antigen were detected. Because the role of organized lymphocytic aggregates at this inflammatory site is not completely understood, we first analyzed the cellular requirements for the formation of these structures. Autoreactive $\mathrm{CD}^{+} \mathrm{T}$ cells were pivotal for tertiary lymphoid follicle formation, most likely in cooperation with dendritic cells, macrophages, and $B$ cells. Second, we analyzed the necessity of secondary lymph nodes and tertiary lymphoid organs for the development of autoimmune gastritis using CCR7 single- and CCR7/lymphotoxin $\alpha$ double-deficient mice. Strikingly, manifestation of autoimmune gastritis was observed in the absence of secondary lymph nodes and preceded the development of tertiary lymphoid organs. Taken together, these findings identify an inflammatory process where gastric autoreactive $T$ cells independent of organized tertiary lymphoid organs and classic lymph nodes can induce and maintain autoimmune gastritis. (Am J Pathol 2011, 179:754-765; DOI: 10.1016/j.ajpath.2011.04.012)
Autoimmunity is often accompanied by the development of tertiary lymphoid organs (TLOs) in the target organ. TLO formation has been reported in inflamed tissues of various autoimmune diseases, including rheumatoid arthritis, Sjögren's syndrome, type 1 diabetes mellitus, and autoimmune gastritis (AIG). ${ }^{1-5}$ Although TLOs share numerous functional characteristics with secondary lymphoid organs (SLOs), their unique function in autoimmune disease pathogenesis is still unclear. 6,7 More specifically, it remains to be elucidated whether these structures are relevant for priming of T cells, development of autoantibody-producing plasma cells, and accumulation of autoantigen-specific T- and B-cell clones.

In a murine AIG model induced by neonatal thymectomy, Katakai and colleagues found ectopic lymphoid organization in the chronic gastric lesions. Number and size of ectopic gastric lymphoid clusters could be correlated with serum autoantibody titers, although development of typical germinal centers (GCs) was rare in this AIG mouse model. ${ }^{5,8}$ In a nonobese diabetic mouse model of type 1 diabetes, the presence of GCs, a skewed repertoire, and somatic hypermutation of B-cell receptors was described in islet TLOs, which implies that T- and B-cell interactions take place at the inflamed site. ${ }^{4}$ More recently, a CXCL13-dependent $B$ lymphocyte lodging within islet TLOs was shown. On CXCL13 blockade, Blymphocyte organization in TLOs was completely abrogated. ${ }^{9}$ However, induction of a skewed B-cell repertoire, occurrence of somatic hypermutation, and finally manifestation of diabetes were maintained. Thus, the authors concluded that the significance of organized TLOs in modulating autoimmune responses remains questionable. In contrast, other studies suggested that formation of TLOs in affected organs contributes essentially to the pathogenesis of human autoimmune diseases by enhancing the efficiency of autoantigen presentation at the

Supported by the Priority Program SFB 633 of the German Research Foundation.

Accepted for publication April 12, 2011.

Supplemental material for this manuscript can be found at $h t t p: / / a j p$. amjpathol.org or at doi: 10.1016/j.ajpath.2011.04.012.

Address reprint requests to Uta E. Höpken, Ph.D., Max-Delbrück-Center for Molecular Medicine, 13125 Berlin, Germany. E-mail: uhoepken@ mdc-berlin.de. 
site of inflammation. In this process, autoreactive T lymphocytes and autoantibody-producing B cells could be generated. ${ }^{7}$ Thus, TLOs may play a role in maintaining an autoimmune response against persistent self-antigens and selection of autoreactive B and T cells. ${ }^{4}$ However, the contribution of autoantibodies to disease progression is still controversially discussed. There is evidence that lymphoid neogenesis is associated with local antibody production but not with autoimmune activity or severity. ${ }^{7}$

AIG represents an organ-specific autoimmune disease in which lymphocytes massively infiltrate the gastric mucosal (GM) tissue, which eventually leads to gastric lymphoid neogenesis. Loss of gastric parietal and zymogenic cells and the prevalence of circulating autoantibodies to gastric parietal antigen are specific characteristics. ${ }^{10}$ The morphology of mouse gastritis shares many pathohistologic and immunologic characteristics with the human disease and can be induced in a variety of experimental approaches, including lymphopenic and nonlymphopenic AIG models, or in T-cell receptor $\alpha$-subunit and T-cell receptor $\beta$-subunit transgenic mice. ${ }^{11}$ Models of spontaneous AIG disease pathogenesis are rare, and disease incidence is often very low. ${ }^{11,12}$

We report the development of an early, spontaneous AIG with almost complete penetrance in mice lacking the homeostatic chemokine receptor CCR7. CCR7 is a major lymph node-homing receptor for lymphocytes and dendritic cells (DCs), and mice that lack CCR7 display not only a delayed induction of adaptive immune responses ${ }^{13,14}$ but also impaired lymphocyte recirculation through nonlymphoid organs. ${ }^{15,16}$ Lack of CCR7 is associated with a moderate multiorgan autoimmunity ${ }^{17}$ and formation of TLOs at mucosal sites. ${ }^{16,18}$ Our results show that $\mathrm{AIG}$ in $\mathrm{CCR} 7^{-1-}$ mice occurred as early as 4 weeks of age characterized by lymphocytic mucosal infiltrates, profound loss of parietal cells, increase in the population of mucous cells, and the occurrence of circulating autoantibodies to gastric antigen. AIG manifestation in these mice was associated with the development of gastric TLOs. We focused on the requirement of TLOs and lymph nodes (LNs) for the pathogenesis of spontaneous AIG. We show that local accumulation of autoreactive $T$ lymphocytes promoted the development of spontaneous AIG in CCR7-deficient mice, a process that was independent from the occurrence of TLOs or classic peripheral LNs.

\section{Materials and Methods}

\section{Mice}

C57BL/6 Ly5.1 (CD45.1) congenic mice, lymphotoxin (Lt) $\alpha^{-1-}$ mice, ${ }^{19}$ and Rag2 ${ }^{-1-}$ mice were obtained from Jackson Laboratories (Bar Harbor, ME). CCR7 ${ }^{-1-}$ were generated as previously described ${ }^{13}$ and backcrossed onto a C57BL/6 background for 12 generations. CCR7 ${ }^{-1-}$ mice were crossed with $\mathrm{Lt} \alpha^{-1-}$ mice to generate double knockout mice. CD11c.DTR transgenic mice were obtained from Natolio Garbi. ${ }^{20}$ Animals were housed in a specific pathogen-free facility at the Max-Delbrück-Center for Molecular Medicine, Berlin, Germany. All animal studies were per- formed according to institutional and Berlin State guidelines (registered under LaGeSo 0184/04 and 0371/05).

\section{Determination of Gastric $\mathrm{pH}$}

Mice were fasted overnight and sacrificed, $50 \mu \mathrm{L}$ of gastric contents was collected, and the $\mathrm{pH}$ was determined using pH paper (Whatman; GE Healthcare, Munic, Germany)

\section{Antibodies}

The following primary antibodies were used: fluorescein isothiocyanate (FITC)-conjugated Armenian hamsteranti-mouse $\mathrm{CD} 3 \varepsilon$; phycoerythrin (PE)-labeled Armenian hamster-anti-mouse CCR5 (CD195); biotinylated Armenian hamster anti-mouse CXCR3 (CD183); FITC-labeled Armenian hamster anti-mouse CD69; PE-conjugated rat anti-mouse CD44; allophycocyanin (APC)-labeled rat anti-mouse CD4, CD8, and CD19; FITC-labeled rat anti-mouse CD86; PE-labeled rat anti-mouse CD23; PE-labeled rat-anti-mouse CD $8 \alpha$; peridinin chlorophyll protein complex (PerCP)-labeled rat anti-mouse CD8 $\alpha$; PerCP-labeled Armenian hamster anti-mouse CD3 $\varepsilon$; PEcoupled Armenian hamster anti-mouse CD103 (all from BioLegend, Kithorn, the Netherlands); FITC-labeled rat anti-mouse CD21/CD35, IgD; FITC-labeled mouse antimouse I-A ${ }^{\text {b }}$; PE-labeled rat anti-mouse IgM (all from BD Biosciences, Heidelberg, Germany); FITC-conjugated rat anti-mouse interferon (IFN)- $\gamma$ and APC-conjugated rat anti-mouse interleukin 17A (IL-17A) (eBioscience, Frankfurt, Germany); and biotinylated Armenian hamster antimouse CD11c (Caltag, Hamburg, Germany). Biotinylated primary antibodies were detected with streptavidin conjugates (BioLegend).

For immunohistology, the following primary antibodies were used: mouse-anti-proton pump/H,K-adenosine triphosphatase (ATPase) $\alpha$-subunit (MBL International Corporation, Woburn, MA); purified rat-anti-mouse CD138; FITC-labeled mouse-anti-mouse CD45.1; Pacific bluelabeled mouse-anti-mouse CD45.2 (all from Biolegend); Alexa 488-labeled rat-anti-mouse CD45R/B220; Pacific blue-labeled rat-anti-mouse CD3; biotinylated rat-antimouse CD45R/B220; and biotinylated Armenian hamsteranti-mouse CD11c (all from BioLegend). Biotinylated Ulex europaeus agglutinin I (UEAI; Vector Laboratories, Loerrach, Germany) and FITC-labeled Griffonia simplicifolia lectin (Invitrogen, Darmstadt, Germany) were used to identify pit and mucous neck cells, respectively.

\section{Flow Cytometry Analysis}

Data were acquired on a FACSCanto II flow cytometer (BD Biosciences) and analyzed with Flowjo software versions 8.8.2 and 9.2 (TreeStar, Ashland, OR).

\section{Immunohistology}

For Alcian blue staining, paraffin sections were deparaffinized, incubated with Alcian blue solution $(\mathrm{pH} 2.5)$ for 30 minutes at room temperature, rinsed in water, dehy- 
drated, and mounted in Entellan (Merck, Darmstadt, Germany). Images were acquired with a Zeiss Axiophot fluorescence microscope with an Axiocam HRc camera and further processed using AxioVision 4.5 software (all from Carl Zeiss, Göttingen, Germany).

\section{Mononuclear Cell Preparation from Mucosal Tissue and SLOs}

Minced tissue of murine stomachs was incubated in RPMI 1640 medium and supplemented with 10\% fetal calf serum and $6 \mathrm{mg} / \mathrm{mL}$ of collagenase NB4 (Serva, Heidelberg, Germany) for 30 minutes at $37^{\circ} \mathrm{C}$. Spleen and mesenteric LNs (mLNs) were injected with $2 \mathrm{mg} / \mathrm{mL}$ of collagenase NB4, cut into small pieces, and incubated at $37^{\circ} \mathrm{C}$ for 30 minutes. Single-cell suspensions were applied on a Ficoll density gradient.

\section{Detection of IFN- $\gamma$ - or IL-17A-Producing Gastric T Cells}

Mononuclear cells were isolated from the stomach and incubated for 4 hours at $37^{\circ} \mathrm{C}$ in RPMI 1640 medium containing $10 \%$ fetal calf serum in the presence or absence of a cocktail of ionomycin $(1.5 \mu \mathrm{g} / \mathrm{mL})$, phorbol myristate acetate (40 $\mathrm{ng} / \mathrm{mL})$, and brefeldin A (20 $\mu \mathrm{g} / \mathrm{mL})$ (Sigma-Aldrich, Munich, Germany). Surface expression of CD3, CD4, and CD8 and intracellular expression of IFN- $\gamma$ and IL-17A (Fix \& Perm cell permeabilization kit; Caltag) were analyzed by flow cytometry.

\section{Determination of Secreted Inflammatory Cytokines}

Stomach tissue of 2-month-old mice was cut into pieces and incubated in $1.25 \mathrm{~mL}$ of serum-free RPMI 1640 medium containing penicillin and streptomycin for 31 hours at $37^{\circ} \mathrm{C}$ and $5 \% \mathrm{CO}_{2}$. Supernatants were harvested and assayed for secreted IL- $1 \beta$, tumor necrosis factor (TNF)- $\alpha$, IFN- $\gamma$, IL-6, IL-10, CCL2 (monocyte chemotactic protein 1), and IL-12p70 using the Cytometric Bead Array Mouse Inflammation Kit and FCAP Array Software (all from BD Biosciences) according to the manufacturer's instructions. Cytokine concentration was indicated by the fluorescent intensity and finally normalized to stomach weight.

\section{Laser Capture Microdissection and Quantitative PCR}

Gastric epithelial tissue from C57BL/6 wild-type (Wt) and $\mathrm{CCR} 7^{-1-}$ mice and TLOs from stomachs of $\mathrm{CCR} 7^{-1-}$ mice were laser microdissected using the PixCell Ile LCM System (Arcturus, Mörfelden-Walldorf, Germany). Cryosections of gastric tissue were mounted on diethyl pyrocarbonate-treated slides, stained, and dehydrated using the HistoGene LCM frozen section staining kit (Arcturus). RNA was isolated using the PicoPure RNA Isolation Kit, followed by two-round amplification of RNA using the RiboAmp Plus Kit (both from Arcturus). For gene expression analysis, antisense RNA was reverse transcribed to cDNA and quantitative
PCR was performed in an array format (SABiosciences, Qiagen $\mathrm{GmbH}$, Hilden, Germany).

\section{Immunoblotting}

Stomach tissue lysates were prepared in lysis buffer (100 $\mathrm{mmol} / \mathrm{L}$ Tris, $\mathrm{pH}$ 7.5, $150 \mathrm{mmol} / \mathrm{L} \mathrm{NaCl}, 1 \mathrm{mmol} / \mathrm{L}$ EDTA$\mathrm{Na}_{2}, 1 \mathrm{mmol} / \mathrm{L}$ sodium orthovanadate, $1 \mathrm{mmol} / \mathrm{L} \mathrm{NaF}, 1 \%$ Triton X-100, and protease inhibitors), and $30 \mu \mathrm{g}$ of protein was separated by SDS-PAGE. Blots were probed with mouse-anti-proton pump/H,K-ATPase $\alpha$-subunit antibody (MBL International Corporation) and polyclonal rabbit-anti-glyceraldehyde-3-phosphate dehydrogenase (GAPDH) antibody (Abcam), followed by horseradish peroxidase (HRP)-coupled goat anti-mouse or donkey anti-rabbit secondary antibody. Proteins were visualized by chemiluminescence (ECL kit; Thermo Scientific, Bonn, Germany). Densitometric quantification of blot bands was performed using the ImageJ software version $1.42 \mathrm{q}$ $(\mathrm{NIH})$.

\section{Mixed Bone Marrow Chimeras}

Bone marrow (BM) from 6- to 12-week-old Wt and $\mathrm{CCR}^{-1-}$ mice was transplanted into 8- to 12-week-old, sex-matched Rag2 ${ }^{-1-}$ mice. Recipients were sublethally irradiated (7 grays) and reconstituted with 2 to $3 \times 10^{7}$ mixed BM cells (1:1) from Wt C57BL/6/CD45.1 and CCR7 ${ }^{-1-}$ C57BL/6/CD45.2 donor mice.

\section{Detection of Autoantibodies and Cytokines by Enzyme-Linked Immunosorbent Assay}

Microtiter plates were coated with $10 \mu \mathrm{g} / \mathrm{mL}$ of whole Wt stomach tissue lysate and incubated with sera at a dilution of 1:50. Bound IgG antibodies were detected using HRPconjugated rabbit anti-mouse antiserum (1:4000, Southern Biotechnology, Aachen, Germany) in conjunction with 3,3',5,5'-tetramethylbenzidine (TMB) substrate (BD).

To quantitate serum IL-17 levels, microtiter plates were coated with rat anti-mouse IL-17A (BioLegend). Serum samples were diluted 1:30 and recombinant mouse IL-17A served as a standard. Bound cytokines were detected with biotinylated rat-anti-mouse IL-17A (BioLegend), followed by HRP-conjugated streptavidin and TMB substrate.

\section{Depletion of $\mathrm{CD}^{+}$Lymphocytes and CD11c ${ }^{+}$DCs}

$\mathrm{CCR} 7^{-1-}$ mice were injected weekly with 50 to $100 \mu \mathrm{g}$ of $\mathrm{CD}^{+}$cell-depleting antibody GK1.5 antibody (BioLegend) or isotype control antibody (rat lgG2b, $\kappa$ ) starting at 2 weeks of age. CD11c.DTR mice, in which the diphtheria toxin receptor (DTR) is under the control of the CD11c promoter, were used to deplete DCs. ${ }^{20}$ Eight DT $(8 \mathrm{ng} / \mathrm{g}$ of body weight) i.p. injections in CCR ${ }^{-1-}$ CD11c.DTR transgenic mice every second day induced the depletion of $\mathrm{CD} 11 \mathrm{C}^{+}$ DCs. 
A

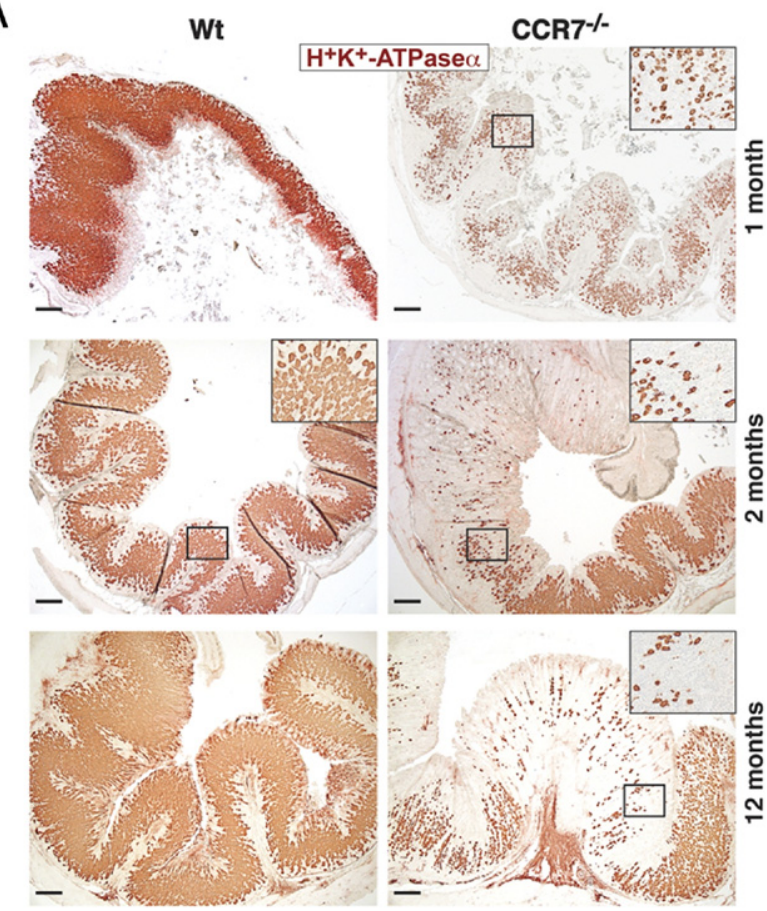

B

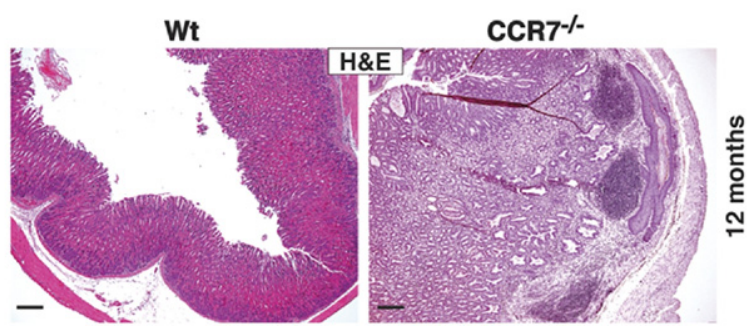

Figure 1. Lack of CCR7 causes early development of AIG. A: Paraffinembedded stomach sections of 1-, 2-, and 12-month-old Wt ( $n=3$ to 5 per age group) or $\mathrm{CCR}^{-1-}$ mice ( $n=3$ to 5 per age group) were immunohistochemically stained for $\mathrm{H}^{+} / \mathrm{K}^{+}$-ATPase $\alpha$ as a marker for parietal cells. Representative stains are shown. Magnification of representative areas in the insets. Scale bar $=200 \mu \mathrm{m}$. B: Paraffin-embedded stomach sections of age-matched (12-month-old) Wt $(n=3)$ and CCR $7^{-/-}$mice $(n=5)$ were stained with H\&E (one representative animal of each group is shown).

\section{Statistical Analysis}

Results are expressed as arithmetic mean \pm SD or SEM, as indicated. $P<0.05$ was considered statistically significant and determined by either the Mann-Whitney $U$-test (one-tailed or two-tailed) or an unpaired, two-tailed Student's $t$-test, as indicated.

\section{Results}

\section{Spontaneous Development of AIG in CCR7- Deficient Mice with Profound Parietal Cell Loss and Mucosal Lymphoid Neogenesis}

We previously reported that the gastrointestinal mucosal tissue of $\mathrm{CCR}^{-1-}$ mice is highly permissive for the formation of TLOs. In aged mice, histologic analysis revealed enlarged stomachs with profound cystic hyperplasia and an increased rate of mucosal proliferation. ${ }^{16}$
Here, immunohistologic analysis of 1- to 12-month-old $\mathrm{CCR} 7^{-1-}$ mice showed that all animals developed distinct histologic and immunohistologic features characteristic of an AIG. Staining for $\mathrm{H}^{+} / \mathrm{K}^{+}$-ATPase $\alpha$, a marker for parietal cells, revealed a selective loss of parietal cells in $\mathrm{CCR} 7^{-1-}$ mice (Figure 1A). Atrophy of parietal cells was accompanied by profound lymphoid neogenesis (Figure 1B) exhibiting GC formation in gastric TLOs of aged mice (see Supplemental Figure S1A at http://ajp.amjpathol. org). The incidence of AIG manifestation was more than $95 \%$ in all age groups of CCR $7^{-1-}$ mice ( 1 month, $n=5$; 2 months, $n=13$; 10 to 16 months, $n=6$ ), whereas $\mathrm{Wt}$ mice did not develop any signs of AIG up to 12 months of age. Parietal cell loss was quantitated by immunoblot analysis showing significantly less protein expression for parietal cell antigen $\mathrm{H}^{+} / \mathrm{K}^{+}$-ATPase $\alpha$ in whole stomach tissue lysates derived from $\mathrm{CCR} 7^{-1-}$ compared with $\mathrm{Wt}$ mice (Figure 2, A and B).

Sonic hedgehog (Shh) is abundantly expressed in the gastric fundic glands, and signaling by Shh protein plays an important role in the maintenance of gastric fund gland homeostasis. ${ }^{21,22}$ Because it was described that parietal cell loss is correlated with reduced expression levels of Shh, ${ }^{23,24}$ we quantitated Shh expression in $\mathrm{CCR} 7^{-1-}$ mice. $\mathrm{CCR}^{-1-}$ mice exhibited decreased gastric Shh gene expression levels (Figure 2C) and hypochlorhydria (Figure 2D) compared with Wt controls. The inflammatory cytokine IL-1 $\beta$ can inhibit parietal cell acid secretion by promoting gastric atrophy through suppression of Shh. ${ }^{24}$ Thus, we analyzed whether local gastric $\mathrm{IL}-1 \beta$ levels might be altered in $\mathrm{CCR} 7^{-1-}$ mice. $\mathrm{CCR} 7^{-1-}$
A

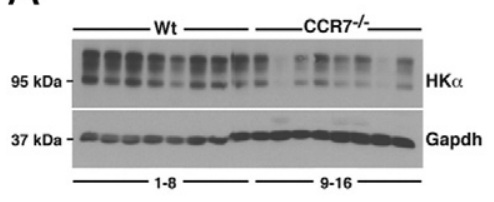

B

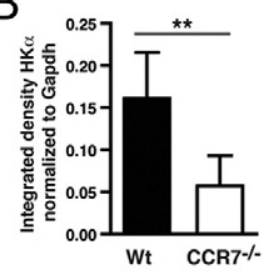

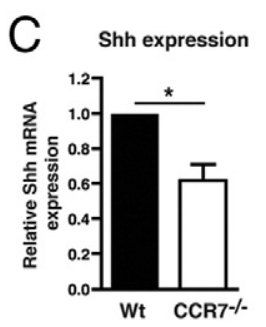

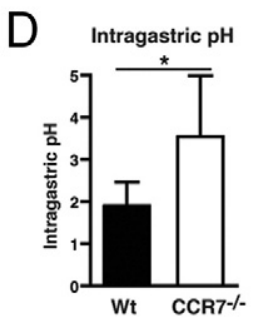

$E$

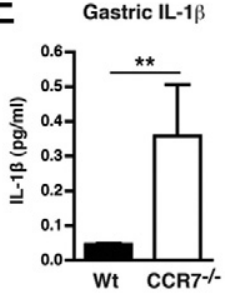

Figure 2. Parietal cell loss in $\mathrm{CCR}^{-/-}$mice is associated with decreased gastric Shh mRNA levels, hypochlorhydria, and increased levels of IL-1 $\beta$. A: Immunoblotting for parietal $\mathrm{H}^{+} / \mathrm{K}^{+}$-ATPase $\alpha(\mathrm{HK} \alpha)$ and GAPDH in stomach tissue lysates of 11- to 23-month-old Wt ( $n=8$; lane 1-8) and CCR7 ${ }^{-7}$ ( $n=8$; lane 9-16) mice. B: Quantitation of $\mathrm{H}^{+} / \mathrm{K}^{+}$-ATPase $\alpha$ protein expression normalized to GAPDH is shown. C: Quantitative PCR for Shh mRNA transcript in stomachs of 2-month-old Wt $(n=6)$ and $\mathrm{CCR}^{-1}{ }^{-}(n=$ 6) mice. Expression of Shh mRNA was normalized to GAPDH and is depicted as relative gastric Shh mRNA expression in $\mathrm{CCR} 7^{-1-}$ compared with Wt (set arbitrarily to 1) mice. D: Measurement of intragastric $\mathrm{pH}$ in 11- to 23-monthold Wt $(n=7)$ and $\mathrm{CCR}^{-/-}(n=6)$ mice using $\mathrm{pH}$ indicator paper. E: Determination of IL- $1 \beta$ secretion from stomachs of 2 -month-old Wt $(n=5)$ and CCR $7^{-\prime-}(n=5)$ mice. Stomach-derived cells were cultured for 31 hours in RPMI 1640 medium without serum at $37^{\circ} \mathrm{C}$. IL- $1 \beta$ release was measured in supernatants by cytokine bead array. Bars represent means $\pm \mathrm{SD}(\mathbf{B}$ and $\mathbf{D})$ or SEM $(\mathbf{C}$ and $\mathbf{E}) .{ }^{*} P<0.05,{ }^{* *} P<0.01$; Mann-Whitney $U$-test. 


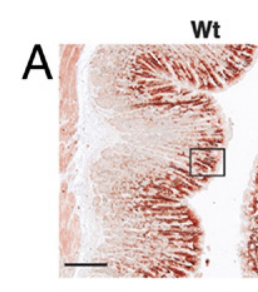

Wt
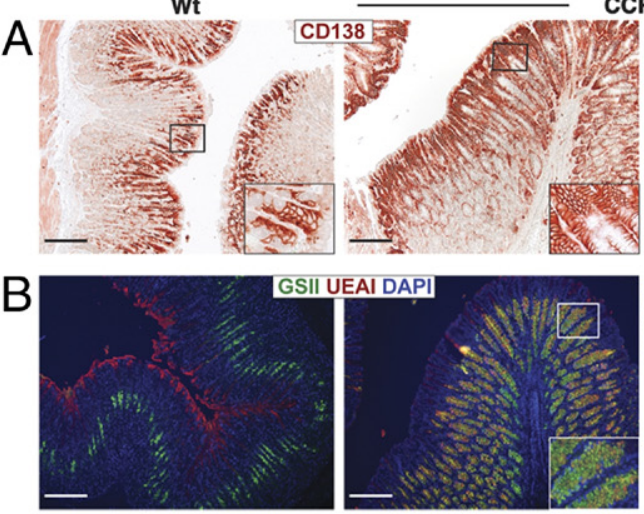

Figure 3. Lack of CCR7 leads to gastric intestinal metaplasia. Stomach sections of 2-month-old Wt or $\mathrm{CCR}^{-1-}$ mice ( $n=5$ per group) were stained for CD138 expression (pit and plasma cells) (A) or triple-stained with lectins UEAI (red, pit cells), GSII (green, mucous neck cells), and DAPI (blue) (B). C: Paraffin-embedded stomach sections of 1-, 2-, and 12-month-old Wt or $\mathrm{CCR}^{-1-}$ mice ( $n=3$ to 5 per group) were stained for acidic mucopolysaccharides (Alcian blue: $\mathrm{pH}$ 2.5). Magnification of representative areas in the insets. Scale bar $=200 \mu \mathrm{m}$.

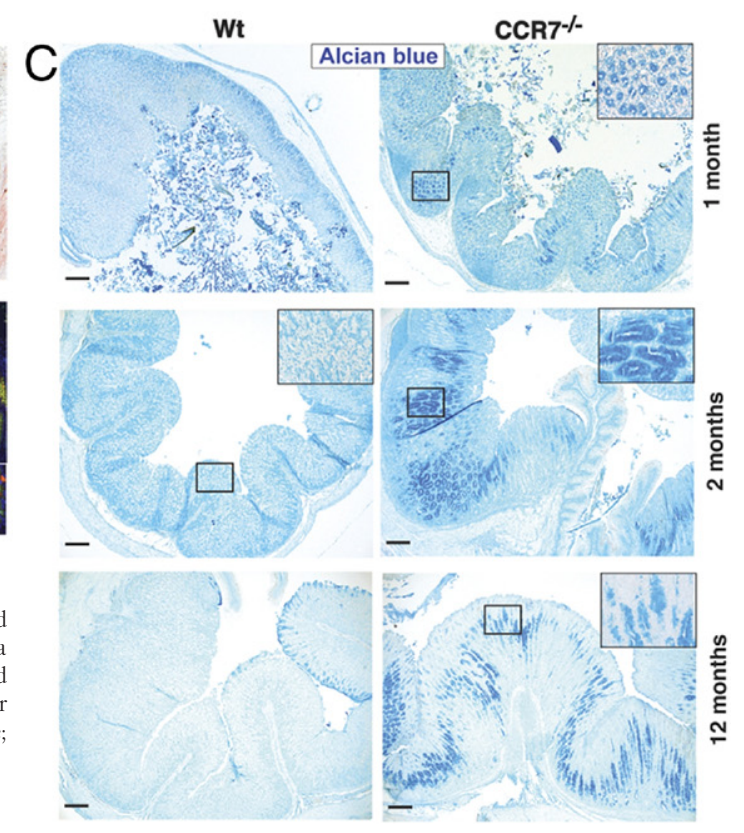

mice revealed a significant increase in gastric $\mathrm{IL}-1 \beta$ production compared with Wt mice (Figure $2 \mathrm{E}$ ), suggesting that enhanced IL- $1 \beta$ expression induces down-regulation of Shh. Gastric secretion of additional proinflammatory cytokines, ie, IL-6, IL-10, TNF- $\alpha$, CCL2 (monocyte chemotactic protein 1), and IL-12p70, was not enhanced in $\mathrm{CCR} 7^{-\prime-}$ mice (data not shown).

\section{Replacement of Parietal Cells by Aberrant Mucous-Producing Cells}

Loss of gastric glandular cells frequently leads to a severe alteration of the normal gastric pit architecture, most likely through replacement by intestinal or fibrous tissues. ${ }^{25}$ Here, stomach sections of 2-month-old Wt or knockout mice were stained for CD138 expression, a marker for gastric pit (foveolar epithelial) cells. The $\mathrm{CD}_{138^{+}}$cell population was markedly increased in $\mathrm{CCR}^{-1-}$ compared with Wt mice (Figure $3 \mathrm{~A}$ ). In addition, single $\mathrm{CD}_{138^{+}}$plasma cells were frequently detected within the lamina propria of $\mathrm{CCR} 7^{-1-}$ mice (Figure $3 \mathrm{~A}$, right panel). To further differentiate between pit cells and mucous neck cells, lectin staining was performed. Pit cells $\left(\mathrm{UEAl}^{+}\right)$lined the gastric surface and were present along pit walls, whereas mucous neck cells $\left(\mathrm{GSII}{ }^{+}\right.$) marked the neck region of the gastric gland in Wt mice (Figure 3B, left panel). In sharp contrast, surface pit cells in $\mathrm{CCR} 7^{-1-}$ mice were found in the vicinity of mucous neck cells and both cell lineages were markedly expanded (Figure 3B, middle and right panels) compared with Wt mice.

Next, we stained stomach sections of $\mathrm{CCR} 7^{-1-}$ mice and Wt controls ( 1 to 12 months old) for acidic mucopolysaccharides (Figure 3C). Extended Alcian blue staining in young and elder $\mathrm{CCR} 7^{-1-}$ mice was indicative of an expansion of acidic mucous-secreting cells, demonstrating metaplasia in $\mathrm{CCR}^{-1-}$ mice. In conclusion,
$\mathrm{CCR}^{-1-}$ mice exhibited a disturbed gastric fundic gland homeostasis with severely impaired differentiation of mucous-producing cells.

\section{Activated Immune Cell Subsets in the Gastric Mucosa of $\mathrm{CCR}^{-1-}$ Mice Are Associated with an Inflammatory Milieu}

Lymphocytes that infiltrate the GM can contribute to epithelial cell destruction and to gastric atrophy during chronic gastritis. ${ }^{26}$ To determine the transcriptional profile of the gastric ectopic lymphoid aggregates in $\mathrm{CCR} 7^{-1-}$ mice versus Wt GM tissue, we microdissected the gastric TLOs and GM tissue of 4- and 12-month-old $\mathrm{CCR}^{-1-}$ and Wt mice, respectively. Quantitative reverse transcription-PCR array analysis focused on genes that were informative on immunoregulatory and proliferative processes. Within gastric TLOs, we detected genes that are commonly associated with an inflammatory milieu, including ILs and IL receptors, ie, IFN- $\gamma$, inflammatory chemokines (CCL3, CCL4, CCL5, CCL6, CCL8, CCL9, CXCL9, CXCL10), chemokine receptors (CCR1, CCR4, CCR5, CXCR3), integrins, and complement factor C3 (see Supplemental Table S1 at $h$ ttp://ajp.amjpathol.org). Genes that were up-regulated in the $\mathrm{GM}$ of $\mathrm{CCR} 7^{-1-}$ mice involved growth factors, adhesion molecules, IFN- $\gamma$, TNF- $\alpha$, proapoptotic genes (Fas, Caspase 1), angiogenesis-associated genes (CXCL5), and the inflammatory cytokine IL-1f6 (see Supplemental Table S2 at http:// ajp.amjpathol.org). Taken together, these results are indicative of a prevalent inflammatory milieu in the GM tissue of $\mathrm{CCR} 7^{-1-}$ mice.

Using flow cytometry, we analyzed the activation status of $\mathrm{CCR} 7^{-1-} \mathrm{GM}$-infiltrating and $\mathrm{mLN}$-derived lymphocytes compared with Wt lymphocytes. Because naive Wt mice do not show any intragastric formation of TLOs, the total number of gastric B and T lymphocytes was small 
A

B
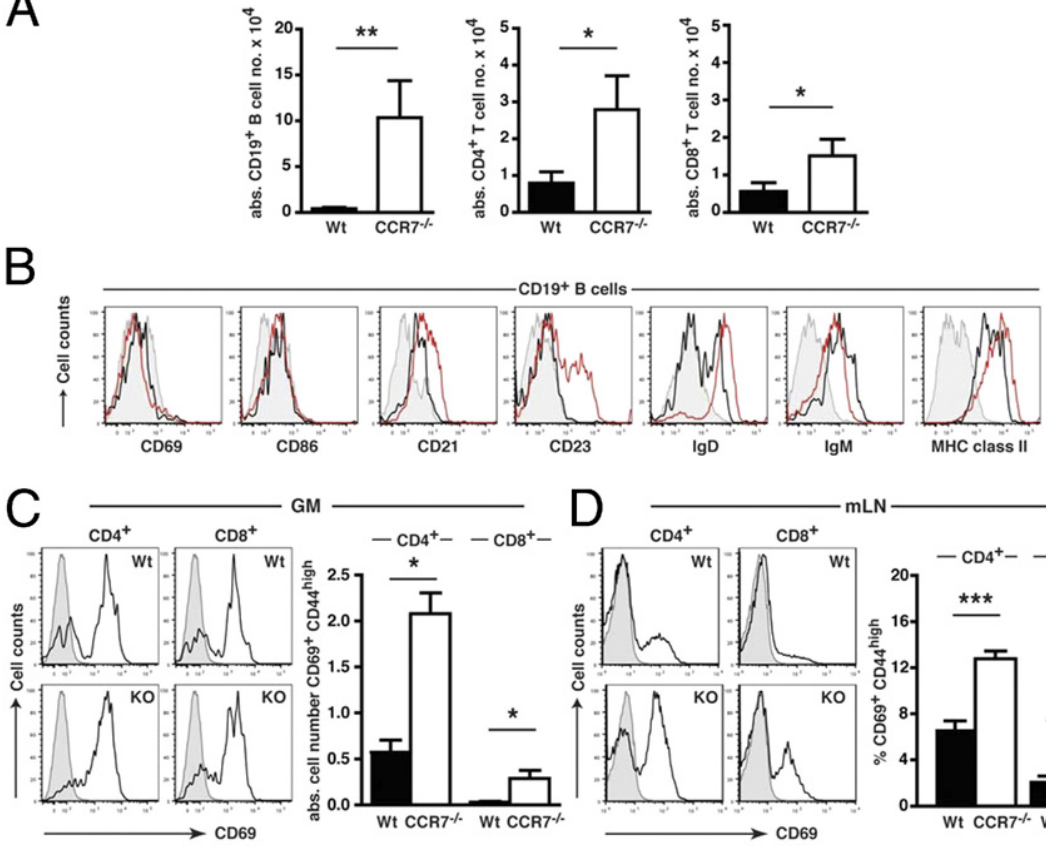

$\mathrm{E}$
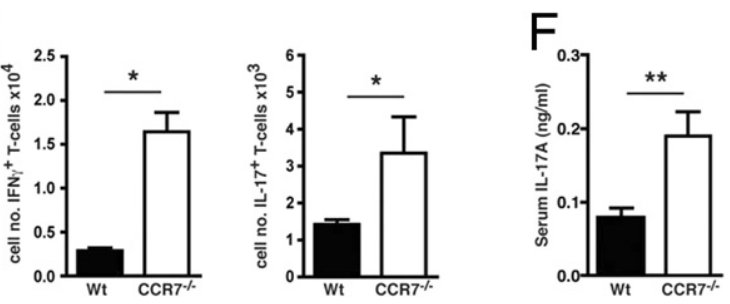

Figure 4. Immune cell subsets of $\mathrm{CCR}^{-/-}$ mice exhibit an activated and inflammatory phenotype within the GM and mLNs. A: Arithmetic means of absolute gastric $\mathrm{CD} 19^{+} \mathrm{B}$ cells and $\mathrm{CD}^{+}$and $\mathrm{CD}^{+}{ }^{+} \mathrm{T}$ cells in the GM tissue of Wt (black bars; $n=12$ to 13 ) and CCR $7^{-1-}$ (open bars; $n=5$ ) mice. Data were calculated from flow cytometric analysis of $\mathrm{CD}^{+} \mathrm{CD}^{+}$and $\mathrm{CD}^{+}{ }^{+} \mathrm{CD}^{+}$expression for T-cell subtypes and $\mathrm{CD} 19^{+}$expression for $\mathrm{B}$ cells of size-gated gastric lymphocytes. B: Flow cytometric analysis of activation and maturation markers on $\mathrm{CD} 19^{+}$ gated B cells isolated from the GM of Wt (black curve; $n=6$ to 9 ) or $\mathrm{CCR} 7^{-/-}$mice ( $n=7$ to 10 ; red curve: isotype control). GM-derived (C) or mLN-derived (D) T-cell subsets (gated on $\mathrm{CD}^{+}$ or $\mathrm{CD}^{+}$) of 6- to 10 -month-old $\mathrm{CCR}^{-/-}$(GM $n=12$; mLN, $n=12$ to 14 ) and Wt mice (GM, $n=9 ;$ mLN, $n=6$ to 8) were stained for CD69 expression and analyzed by flow cytometry (shaded curve: isotype control). Total numbers of activated $\mathrm{CD} 69^{+} \mathrm{CD} 44^{\text {high }}$ T-cell subsets in GM (C; right panel) and percentages of activated $\mathrm{CD} 69^{+}$CD $44^{\text {high }}$ T-cell subsets in $\mathrm{mLN}$ (D right panel) of $\mathrm{Wt}$ and $\mathrm{CCR} 7^{-/-}$mice are shown. E: Flow cytometric analysis of IFN- $\gamma$ or IL-17A production in GM-derived $\mathrm{CD}^{+}{ }^{+} \mathrm{T}$ cells from Wt $(n=9)$ and CCR $7^{-1-}$ mice $(n=3)$ after in vitro culture with $(+)$ or without (-) brefeldin, ionomycin, and PMA. Total numbers of gastric $\mathrm{CD} 4{ }^{+}$IFN- $\gamma^{+}$or $\mathrm{CD} 4^{+} \mathrm{IL}-17 \mathrm{~A}^{+}$cells are shown F: Serum samples from 4- to 6-week-old Wt (black bar; $n=9$ ) and CCR $7^{-/-}$mice (open bar; $n=9$ ) were analyzed for the $\mathrm{T}_{\mathrm{H}} 17$ cytokine IL-17A by enzyme-linked immunosorbent. Bars in $\mathbf{A}-\mathbf{E}$ represent mean \pm SEM. ${ }^{*} P<0.05$, ${ }^{* * *} P<0.01$, and ${ }^{* * * *} P<0.001 ;$ Mann-Whitney $U$-test. and significantly lower compared with $\mathrm{CCR} 7^{-1-}$ mice (Figure 4A). Most gastric CCR7 ${ }^{-1-} \mathrm{CD}_{19}{ }^{+} \mathrm{B}$ cells expressed the common B-cell markers I- $\mathrm{A}^{\mathrm{b}}$ (major histocompatibility complex [MHC] class II), CD21, and CD23 and were $\operatorname{lgM}^{+} / \operatorname{lgD}^{+}$(Figure $4 \mathrm{~B}$ ). A low expression level was found for the co-stimulatory molecule CD86, and no significant staining was detectable for the early activation antigen CD69 (Figure 4B). Hence, CCR7-deficient GMinfiltrating $B$ lymphocytes represent a mature but predominantly nonactivated phenotype comparable to those of Wt mice. The only differences between $\mathrm{CCR} 7^{-1-}$ and Wt $\mathrm{B}$ lymphocytes were a higher percentage of $\mathrm{CD} 23^{+}$ and $\operatorname{lgD}^{+} \mathrm{B}$ lymphocytes in $\mathrm{CCR} 7^{-1-}$ mice, which is because the TLOs in $\mathrm{CCR} 7^{-1-}$ mice predominantly contain classic B-2 B lymphocytes (CD2 $1^{\text {int } C D 23}{ }^{\text {hi }} / \mathrm{lgM} /$ $\lg \mathrm{D}^{\text {hi }}$ ) (Figure 4B). In both strains, $C \mathrm{CR} 7^{-1-}$ and Wt animals, most $\mathrm{GM}$-derived $\mathrm{CD}^{+}{ }^{+}$and $\mathrm{CD}^{+}{ }^{+} \mathrm{T}$ lymphocytes expressed the early activation antigen CD69 (Figure 4C, left panels). Importantly, the overall total number of activated $\mathrm{CD}_{69}{ }^{+} \mathrm{CD} 44^{\text {high }} \mathrm{CD}^{+}{ }^{+}$or $\mathrm{CD}_{69}{ }^{+} \mathrm{CD} 44^{\text {high }} \mathrm{CD}^{+}{ }^{+} \mathrm{T}$ cells was significantly increased in $\mathrm{CCR} 7^{-1-}$ compared with Wt mice (Figure 4C, right panel). CD69 expression was also up-regulated in $40 \%$ to $60 \%$ of $\mathrm{mLN}$-derived $\mathrm{CD}^{+}{ }^{+}$and in $20 \%$ to $30 \%$ of $\mathrm{mLN}$-derived $\mathrm{CD} 8^{+} \mathrm{T}$ cells of $\mathrm{CCR}^{-1-}$ mice compared with $\mathrm{mLN}$-derived CD4 ${ }^{+}(20 \%$ $40 \%)$ and $\mathrm{CD}^{+}(10 \%-15 \%) \mathrm{T}$ lymphocytes of Wt mice (Figure 4D, left panels). The percentage of CD69 ${ }^{+} \mathrm{CD} 4^{+}$ or $\mathrm{CD}^{+} \mathrm{T}$ cells that co-expressed CD44 was additionally increased in $\mathrm{mLNs}$ of $\mathrm{CCR} 7^{-1-}$ compared with Wt mice $\left[6.75 \% \pm 0.64 \%(\mathrm{Wt})\right.$ and $12.8 \% \pm 0.65 \%\left(\mathrm{CCR} 7^{-1-}\right)$ for $\mathrm{CD}^{+}{ }^{+} \mathrm{T}$ cells and $2.26 \% \pm 0.35 \%(\mathrm{Wt})$ and $4.36 \% \pm$ $0.38 \%\left(\mathrm{CCR}^{-1-}\right)$ for $\mathrm{CD}^{+} \mathrm{T}$ cells] (Figure 4D, right panel).

The total number of IFN- $\gamma$ - or IL-17A-producing gastric $\mathrm{CD}^{+} \mathrm{T}$ cells was also significantly elevated in $\mathrm{CCR}^{-1-}$ mice (Figure 4E). In addition, increased IL-17A levels were detected in the serum of young (4 to 6 weeks of age) (Figure 4F) and old (12 months of age; data not shown) $\mathrm{CCR}^{-1-}$ mice compared with Wt mice. The inflammatory phenotype of $\mathrm{CCR} 7^{-1-} \mathrm{T}$ lymphocytes was further supported by chemokine receptor expression. Approximately $10 \%$ of GM-derived T lymphocytes expressed the $\mathrm{T}_{\mathrm{H}}$ 1-associated chemokine receptors CCR5 and/or CXCR3 (see Supplemental Figure S2 at http:// ajp.amjpathol.org). The percentage of $\mathrm{mLN}$-derived $\mathrm{CD} 4^{+}$ $\mathrm{T}$ cells expressing CCR5 and/or CXCR3 was also enhanced in $\mathrm{CCR}^{-1-}$ compared with Wt mice (see Supplemental Figure S2 at http://ajp.amjpathol.org).

\section{$\mathrm{CD4}^{+} \mathrm{T}$ Cells Are Crucial for the Development of AIG and Ectopic Follicular Aggregates in $\mathrm{CCR}^{-1-}$ Mice}

GM-infiltrating T cells, which exhibited an activated phenotype, were most likely involved in the production of 

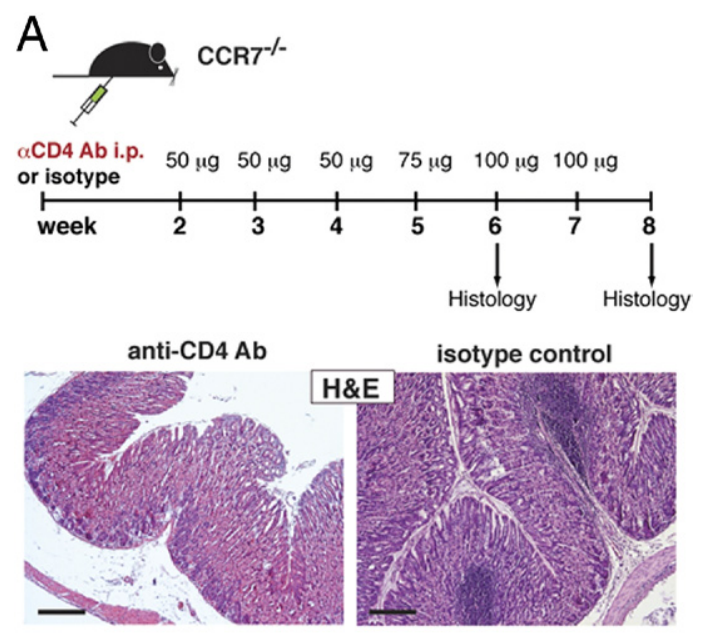

B
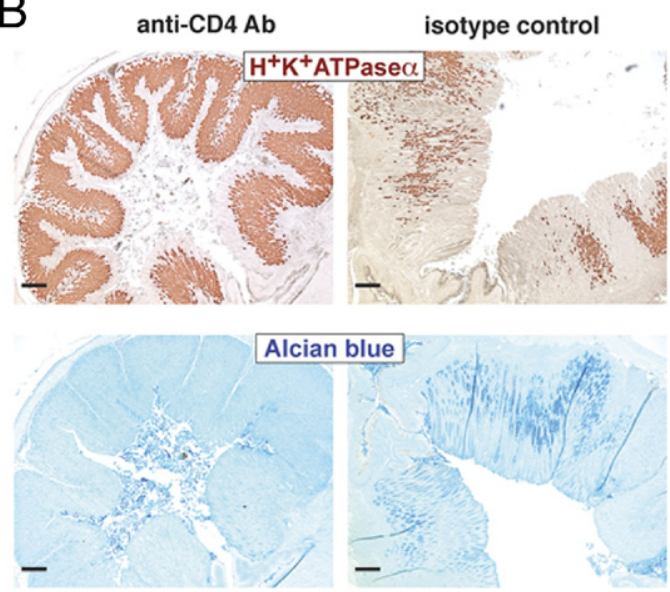

Figure 5. $\mathrm{CD}^{+} \mathrm{T}$ cells are crucial for the development of AIG and ectopic follicular aggregates. A: Schematic representation of $\mathrm{CD} 4^{+} \mathrm{T}$-cell depletion in $\mathrm{CCR}^{-1-}$ mice. CCR $7^{-1-}$ mice were treated with 50 to $100 \mu \mathrm{g}$ (as indicated) of anti-CD 4 antibody or isotype control antibody i.p. starting at 2 weeks of age up to 6 or 8 weeks of age (once per week). B: Paraffin-embedded stomach sections of anti-CD $4 \mathrm{Ab}-(n=5)$ or isotype control antibody-treated mice $(n=7)$ were stained with $\mathrm{H} \& \mathrm{E}$ for parietal cells (brown; $\mathrm{H}^{+} / \mathrm{K}^{+}$ATPase $\alpha$; upper panel) or acidic mucopolysaccharides (Alcian blue; lower panel). Scale bar $=200 \mu \mathrm{m}$.

inflammatory mediators. To assess the role of $\mathrm{CD}^{+}{ }^{+} \mathrm{T}$ lymphocytes, we depleted CD4 ${ }^{+} \mathrm{T}$ cells with an anti-CD4 T-cell antibody starting at the age of 2 weeks until 6 or 8 weeks of age (Figure 5A). Strikingly, the formation of ectopic lymphoid follicles in the $\mathrm{GM}$ of $\mathrm{CCR} 7^{-1-}$ mice was completely abolished, whereas $\mathrm{CCR} 7^{-1-}$ mice treated with an isotype control antibody revealed normal development of TLOs as observed before (Figure 5A). Furthermore, CD4 ${ }^{+}$T-cell-depleted mice did not show any sign of parietal cell loss (Figure 5B, upper panel), and also no development of GM metaplasia (lower panel) could be observed compared with isotype-treated mice. Hence, activated CD4 ${ }^{+} \mathrm{T}$ cells act as crucial effectors and mediators in the development of $\mathrm{AIG}$, including gastric TLO formation in $\mathrm{CCR} 7^{-1-}$ mice.

Gastrointestinal accumulation of regulatory $T$ cells (Tregs) is thought to reinforce the delicate balance between immune activation and tolerance at mucosal sites. ${ }^{27}$ To determine whether Tregs were present in the $\mathrm{GM}$ tissue of $\mathrm{CCR}^{-/-}$mice, we stained stomach sec- tions for the presence of Foxp3 ${ }^{+}$Tregs. Foxp3 ${ }^{+}$Tregs were frequently found within and adjacent to the gastric TLOs in $\mathrm{CCR}^{-1-}$ mice. In comparison, only a few Foxp $^{+}$Tregs were detected in the GM of Wt mice (see Supplemental Figure S1B at http://ajp.amjpathol.org).

To analyze the contribution of DCs to gastric TLO formation, we backcrossed $\mathrm{CCR} 7^{-1-}$ mice with a CD11c DTR transgenic mouse strain. ${ }^{20}$ In nondepleted $\mathrm{CCR} 7^{-/-}$ CD11c.DTR mice, most of the $\mathrm{CD}_{11 \mathrm{C}^{+}} \mathrm{DCs}$ resided within or in close proximity to gastric TLOs (Figure 6A, left panel). Mice at 3 months of age were depleted of DCs over a time period of 14 to 16 days (Figures 6A, right panel, and 6B). Whereas $\mathrm{CD}_{11 \mathrm{C}^{+}} \mathrm{DC}$ depletion in the spleen was efficient (Figure 6B, upper panel), CD11 ${ }^{+}$ $\mathrm{DC}$ depletion in mucosal TLOs of $\mathrm{CCR} 7^{-1-}$ mice was incomplete [Figure 6B (lower panel) and Figure 6C (lower panel)]. Partial depletion of DCs was associated with smaller gastric TLOs in DT-treated CCR $7^{-1-}$ CD11c.DTR mice, but complete resolution of TLOs could not be observed (Figure 6A, right panel). Next, we characterized $\mathrm{DC}$ subsets in the gastrointestinal tissue of $\mathrm{CCR} 7^{-/-}$ mice compared with $\mathrm{DC}$ subsets in $\mathrm{mLNs}$. A unique population of gastric CD11C ${ }^{\text {int }} \mathrm{CD} 103^{+} \mathrm{MHC}$ class IIvariable $\mathrm{CD}^{-}$DC-like cells was found in $\mathrm{CCR} 7^{-1-}$ mice, which was absent from mLNs and from GM tissue of Wt control animals (Figure 6, D and E; see also Supplemental Figure S3 at http://ajp.amjpathol.org).

\section{CCR7 Deficiency Is a Prerequisite for Lymphocyte Retention within Gastric TLOs}

To study whether gastric TLOs would also be permissive for nonautoimmune-reactive Wt lymphocytes, we generated mixed BM chimeras by transplanting BM from $\mathrm{CCR}^{-1-}$ (CD45.2) together with BM from congenic B6 (CD45.1) mice in a 1:1 ratio into sublethally irradiated Rag2 ${ }^{-1-}$ mice (Figure 7A). As a control, sublethally irradiated Rag2 ${ }^{-1-}$ mice were injected with Wt BM only. Three to 8 months after transfer, the frequency of gastric Wt and $\mathrm{CCR} 7^{-1-}$ lymphocytes and the formation of gastric TLOs were analyzed. Rag2 ${ }^{-1-}$ recipients of mixed BM cells exhibited the formation of large TLOs in the submucosa and lamina propria of the stomach accompanied by severe parietal cell loss and gastric metaplasia (Figure 7, B and C). Transfer of Wt BM alone did not cause lymphoid neogenesis (data not shown) or altered mucosal tissue architecture (Figure 7C). The proportion of Wt BM-derived and CCR7 ${ }^{-1-}$ BM-derived lymphocytes within mucosal TLOs revealed a striking difference. Most lymphocytes contributing to the follicular aggregates were of $\mathrm{CCR} 7^{-1-}$ origin, whereas only single Wt lymphocytes were found scattered throughout the lymphoid follicles and within the gastric lamina propria (Figure $7 \mathrm{~B}$ ). In contrast, the ratio of $\mathrm{Wt}$ to $\mathrm{CCR} 7^{-1-}$ lymphocytes in the $\mathrm{mLNs}$ was increased, thus underlining the role of CCR7 as a major LN-homing receptor (data not shown). These results support the notion that only autoreactive $\mathrm{CD} 4^{+} \mathrm{CCR} 7^{-1-} \mathrm{T}$ cells have the ability to lodge within the GM tissue and subsequently give rise to TLOs. 
A
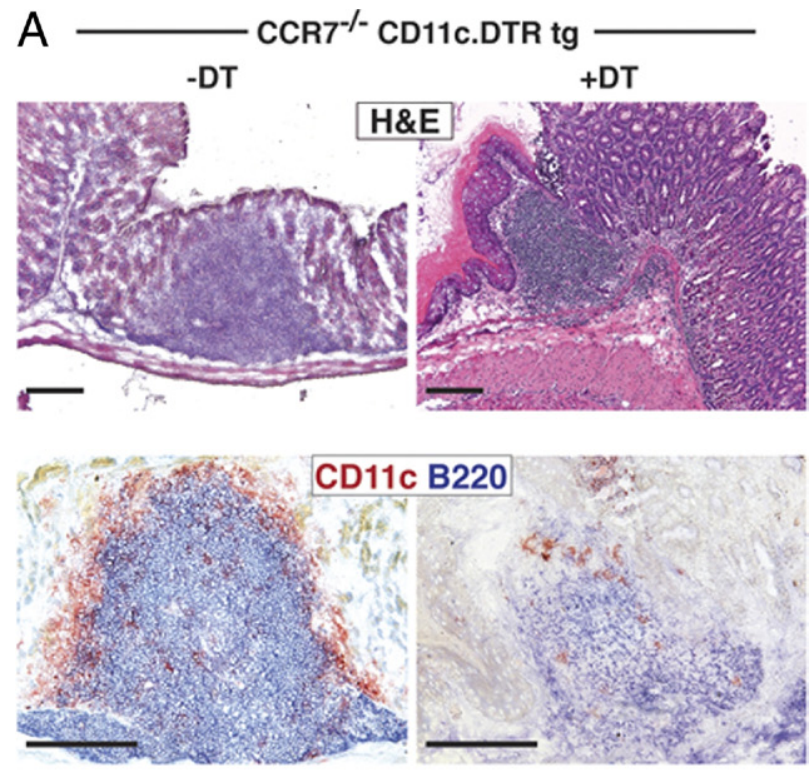

B
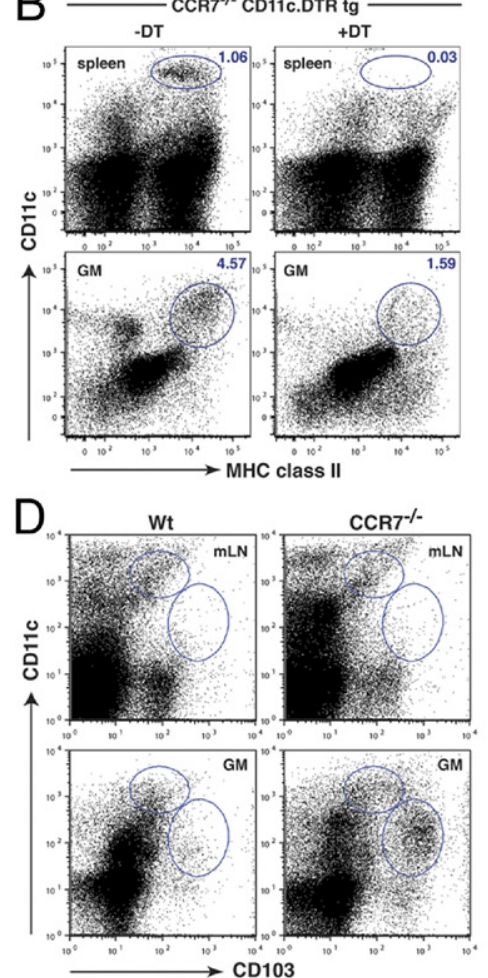

$E$

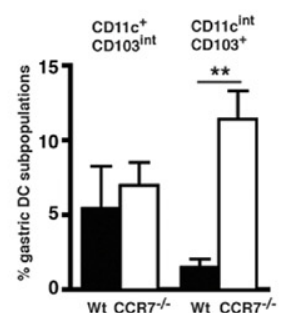

Figure 6. Gastric TLOs of $\mathrm{CCR} 7^{-/-}$mice contain an intestinal type of $\mathrm{CD} 11 \mathrm{c}^{\mathrm{int}} \mathrm{CD}_{103^{+}}$DCs. A: Stomach sections of 3-month-old CCR $7^{-/}$CD11c.DTR transgenic mice, treated with PBS (-DT) or treated with DT (+DT) were stained with H\&E or for CD11c ${ }^{+}$DCs (red) and $\mathrm{B}_{22} 0^{+} \mathrm{B}$ cells (blue). Scale bar $=200 \mu \mathrm{m}$. B: $\mathrm{CD} 11 \mathrm{c}^{+}$DC depletion was analyzed in the spleen and in the GM of 3-month-old $\mathrm{CCR}^{-/-}$CD11c.DTR transgenic mice, treated with PBS (-DT) or DT $(+\mathrm{DT})$, by flow cytometric analysis. Representative dot plots for CD11c and MHC class II expression are shown. C: Percentage of $\mathrm{CD} 11 \mathrm{c}^{+} \mathrm{MHC}$ class $\mathrm{II}^{+}$DCs in the spleen (upper panel) and GM (lower panel) of PBS-treated CCR $7^{-1-}$ CD11c.DTR transgenic (gray bars; $n=4$ ) and DTtreated CCR $7^{-/-}$CD11c.DTR transgenic mice (black bars; $n=4$ ) mice. D: Dendritic cells isolated from GM and mLNs of Wt (GM, $n=3$; mLN, $n=$ 4) and $\mathrm{CCR}^{-1}$ (GM, $\left.n=8 ; \mathrm{mLN}, n=4\right)$ mice ( 2 to 3 months old) were analyzed by flow cytometry analysis. Representative data for CD103 and CD11c expression are shown. E: Quantification of $\mathrm{CD} 11 \mathrm{c}^{+} \mathrm{CD} 103^{\text {int }}$ and $\mathrm{CD} 11 \mathrm{c}^{\text {int }} \mathrm{CD} 103^{+}$DCs in the GM of Wt (black bars) and $\mathrm{CCR} 7^{-/-}$(open bars) mice. Bars represent mean \pm SEM. ${ }^{* *} P<0.01$; Mann-Whitney $U$-test.
Manifestation of AIG Is Independent from Organized TLOs and from Peripheral LNs as Inductive Sites

The involvement of TLOs in the initiation and maintenance of chronic inflammatory autoimmune diseases is still unclear. ${ }^{7}$ To determine whether local TLOs and peripheral LNs are a prerequisite for the development of AIG in $\mathrm{CCR}^{-1-}$ mice, we crossed $\mathrm{CCR} 7^{-1-}$ mice into the $\mathrm{Lt} \alpha^{-1-}$ mouse strain to generate CCR7/Lt $\alpha$ double-deficient $\left(\mathrm{CCR} 7^{-1-} \mathrm{Lt} \alpha^{-1-}\right)$ mice. Lt $\alpha$, which is a member of the TNF family of cytokines, facilitates the development of

A

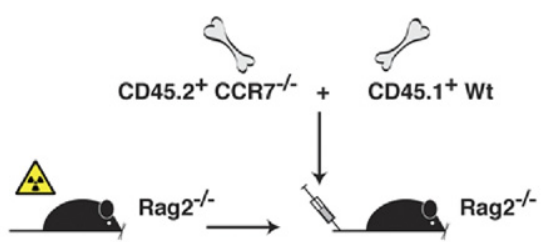

B
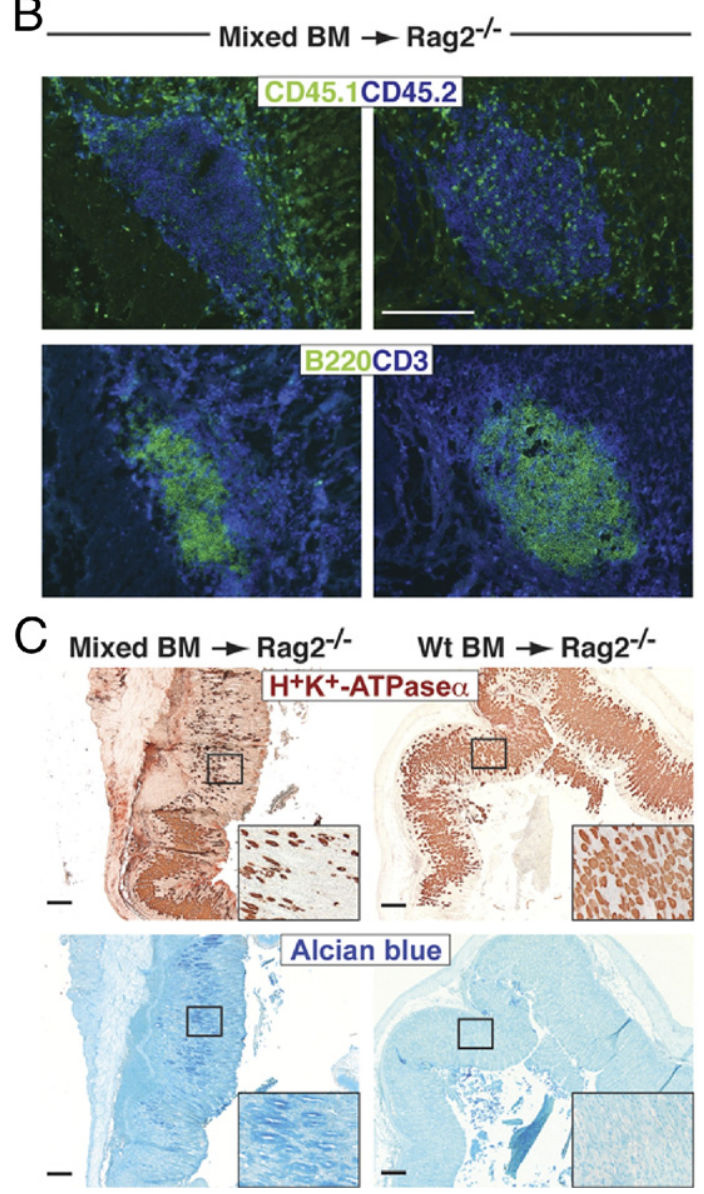

Figure 7. Autoreactive CCR7-deficient lymphocytes induce AIG and gastric TLO formation in Rag2 $2^{-/-}$mice. A: Schematic representation for generation of BM chimeric mice by reconstitution of sublethally irradiated Rag $2^{-/-}$mice with equal numbers of CD $45.2^{+} \mathrm{C} 57 \mathrm{BL} / 6 \mathrm{CCR} 7^{-1-}$ and congenic CD $45.1^{+}$ C57BL/ 6 Wt BM cells. B: Stomach sections were stained for CD $45.1^{+}$(green) and $\mathrm{CD} 45.2^{+}$(blue) cells (upper panel) or $\mathrm{B} 220^{+} \mathrm{B}$ (green) and $\mathrm{CD} 3^{+} \mathrm{T}$ (blue) cells (lower panel). Shown are representative stains of ectopic follicular aggregates in two of seven mice analyzed. C: Paraffin-embedded stomach sections were stained for $\mathrm{H}^{+} / \mathrm{K}^{+}$-ATPase $\alpha$ (brown) or acidic mucopolysaccharides (Alcian blue). Scale bar $=200 \mu \mathrm{m}$. 
organized secondary and tertiary lymphoid tissues. Subsequently, $\mathrm{Lt} \alpha^{-/-}$mice entirely lack $\mathrm{LNs}$ and Peyer's patches (PPS) and have a disrupted splenic architecture. ${ }^{19}$ As expected, CCR $7^{-1-} \mathrm{Lt} \alpha^{-1-}$ mice also lacked all peripheral LNs and failed to develop organized gastric TLOs. However, they displayed unorganized lymphoid infiltrates consisting of B and T lymphocytes (Figure 8A) and macrophages (data not shown) within the GM and
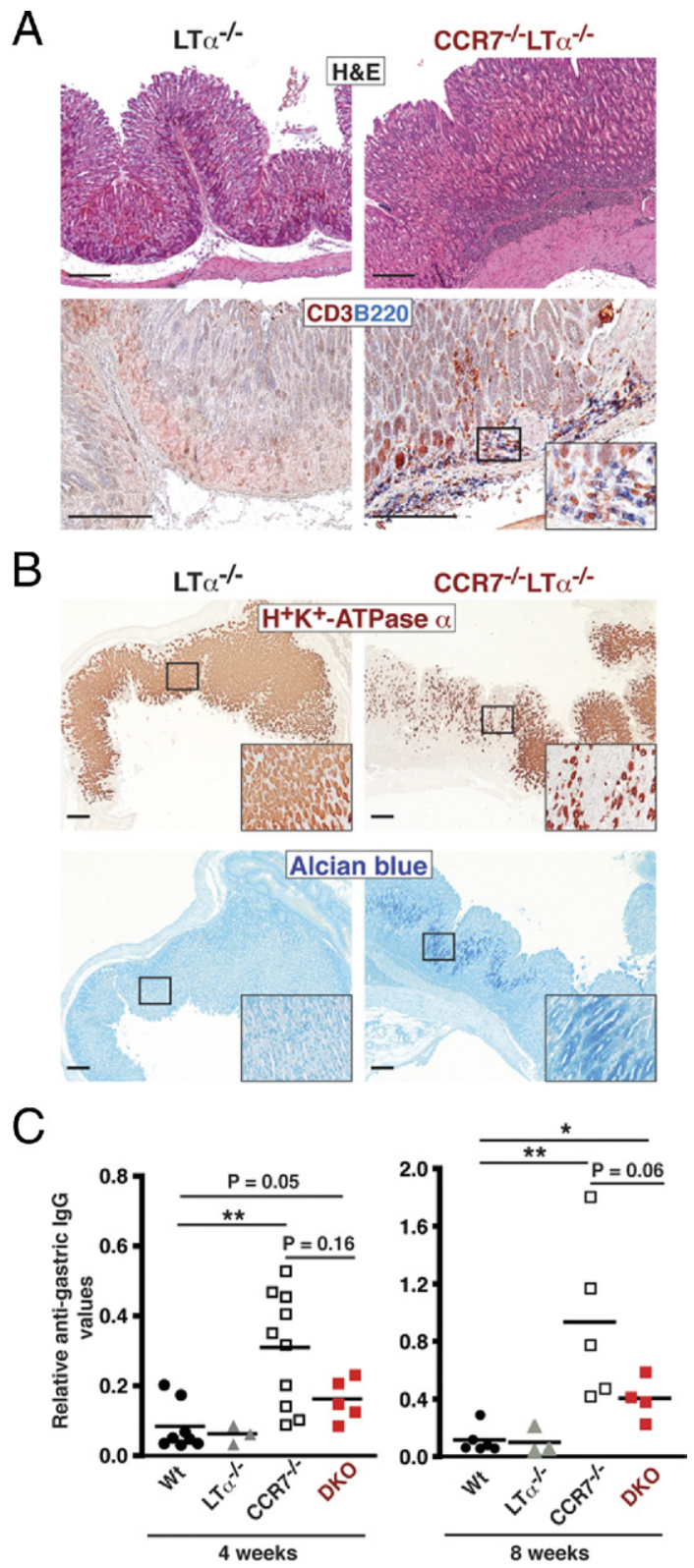

Figure 8. Development of AIG in $\mathrm{CCR} 7^{-/-} \mathrm{Lt} \alpha^{-/-}$mice is independent of organized lymph nodes and gastric TLOs. A: Paraffin-embedded stomach sections from 1- to 2-month-old $\mathrm{Lt} \alpha^{-1-}$ and CCR7 $7^{-1-} \mathrm{Lt} \alpha^{-/-}$double-deficient mice were stained with $\mathrm{H} \& \mathrm{E}$ or for $\mathrm{B} 220^{+} \mathrm{B}$ (blue) and $\mathrm{CD}^{+} \mathrm{T}$ (red) cells. B: Sections from 1- to 2-month-old $\mathrm{Lt} \alpha^{-/-}$and $\mathrm{CCR} 7^{-/-} \mathrm{LT} \alpha^{-/-}$mice were stained for $\mathrm{H}^{+} / \mathrm{K}^{+}$-ATPase $\alpha$ (brown) and acidic mucopolysaccharides (Alcian blue). Scale bar $=200 \mu \mathrm{m}$. C: Relative serum titers of IgG autoantibodies directed against gastric-derived antigen of 1-month-old (left panel) and 2-month-old (right panel) $\mathrm{Wt}, \mathrm{Lt} \alpha^{-1-}, \mathrm{CCR} 7^{-/-}$, and CCR $7^{-/-} \mathrm{Lt} \alpha^{-1-}$ (double knockout; DKO) mice. Serum samples were used at a dilution of 1:50. Absorbance values at $450 \mathrm{~nm}$ represent the relative antigastric IgG. Mean values are shown; ${ }^{*} P<0.05,{ }^{* *} P<0.01$; Mann-Whitney $U$-test. submucosa. The frequency of naïve to activated T cells was not significantly altered in peripheral blood and splenic $\mathrm{T}$ lymphocytes of $\mathrm{CCR} 7^{-1-} \mathrm{Lt} \alpha^{-1-}$ mice compared with Wt mice (data not shown). This was in contrast to the enhanced activation status that we found in peripheral and LN-derived T cells of CCR7 single-deficient mice and suggests that peripheral T cells are predominantly activated in SLOs. Nevertheless, despite the lack of organized gastric TLOs in CCR7 ${ }^{-1-} \mathrm{Lt} \alpha^{-1-}$ mice, we observed substantial loss of parietal cells (Figure 8B, upper panel) accompanied by the development of GM metaplasia (Figure 8B, lower panel). We also determined serum autoantibody titers against gastric antigen. Gastric antigen-specific IgG was significantly increased in $\mathrm{CCR} 7^{-1-}$ compared with Wt mice, whereas $\mathrm{CCR} 7^{-1-} \mathrm{Lt} \alpha^{-1-}$ (double knockout) mice only showed a minor increase (Figure $8 \mathrm{C}$ ). We suggest that in our AIG model, the induction of humoral immune responses is more dependent on organized SLO or TLO structures compared with the induction of T-cell-mediated autoimmune responses.

\section{Discussion}

In the present study, we demonstrate that $\mathrm{CCR} 7^{-/-}$mice develop an early spontaneous AIG with near-complete penetrance. This spontaneous model allowed us to address whether the development of gastric TLOs might contribute to the induction and maintenance of AIG.

The local inflammatory microenvironment, which promotes the formation of TLOs, is mediated by interactions of immune effector cells and tissue-resident cells. Hence, we analyzed the cellular requirements for TLO formation in $\mathrm{CCR} 7^{-1-}$ mice, a process that is believed to mimic several aspects of SLO development. The function of homeostatic chemokines in SLO development and organization is mutually dependent on signaling pathways activated by the TNF/Lt family of cytokines. ${ }^{28,29} \operatorname{Lt} \alpha 1 \beta 2$ expressing lymphoid tissue inducer (LTi) cells are the first cells to colonize the LN anlagen and are absolutely required for neonatal SLO development. However, it is less clear whether LTi cells are required for the formation of TLOs. ${ }^{7,30}$ Transgenic mice overexpressing IL-7 but lacking either ROR $y \mathrm{t}$, a transcription factor needed for LTi cell development, or $L t \alpha 1 \beta 2$ did not support the generation of LNs, PPs, or TLOs. ${ }^{31}$ However, in CCR7 ${ }^{-1-} / \mathrm{ROR}_{\mathrm{ft}}{ }^{-/-}$ double knockout mice, we still observed the development of ectopic follicular aggregates within the GM tissue (U.E. Höpken et al, unpublished data). Thus, in our spontaneous AIG model, the development of gastric TLOs was independent of LTi cells. This is in line with a recent publication by Lochner and coworkers, which showed that in $\mathrm{ROR}^{-1-}$ mice microbiota-induced TLOs could be observed in the absence of LTis. ${ }^{32}$

In transgenic mice that express CCL21 in the thyroid gland, it was found that TLO formation involved the interaction of mature $\mathrm{CD}^{+}{ }^{+} \mathrm{T}$ cells with clusters of DCs, a process mediated by homeostatic chemokines. ${ }^{33}$ In support of a decisive role of $\mathrm{CD}^{+}{ }^{+}$T cells during TLO formation, depletion of all $\mathrm{CD}^{+}{ }^{+} \mathrm{T}$ cells led to a complete 
abrogation of TLO formation in the GM tissue of $\mathrm{CCR} 7^{-1-}$ mice. Notably, on transplantation of $\mathrm{CCR} 7^{-1-} \mathrm{Nt}$ mixed $\mathrm{BM}$ into $\mathrm{Rag}^{-1-}$ recipients, gastric TLOs frequently developed but were populated predominantly by $\mathrm{CCR} 7^{-1-}$. derived lymphocytes. This suggests that only activated and putatively autoreactive CCR7 ${ }^{-1-}$ lymphocytes contribute to ectopic gastric lymphoid cell clusters. In addition, we and others recently showed that CCR7 deficiency led to an impaired lymphocytic recirculation and subsequently caused accumulation of lymphocytes in nonlymphoid tissues. ${ }^{15,34}$ This might cause an extended residence time of putatively autoreactive lymphocytes at mucosal sites and thereby support the development of AIG and the formation of gastric TLOs.

A recent publication showed that $C D 11 c^{+}$DCs are essential for the maintenance of TLOs in the lungs of influenza virus-infected CD11c.DTR transgenic mice. ${ }^{35}$ To further address the cellular requirements for TLO formation, we depleted DCs via administration of DT in CCR $7^{-1-}$ CD11c.DTR transgenic mice. We obtained an ineffective depletion of $\mathrm{CD}_{11 \mathrm{c}^{+}} \mathrm{DCs}$ in gastric TLOs compared with a near-complete depletion of DCs in the spleen. Incomplete depletion of a CD11 $\mathrm{c}^{\text {int/lo }} \mathrm{DC}$ population has already been shown by Garbi et al, ${ }^{20}$ an effect that was explained by lower expression of the DTR in these cells. In CCR7 ${ }^{-1-}$ mice, we showed a unique population of gastric $\mathrm{CD} 11 \mathrm{c}^{\text {int }} \mathrm{CD}_{103^{+}} \mathrm{DCs}$, which was clearly absent from $\mathrm{mLNs}$ and GM tissue in Wt mice. Thus, in our model we envisage that reduced CD11c expression of this gastric TLO-associated subpopulation of DCs is responsible for their ineffective depletion. A functional subset of intestinal $\mathrm{CD} 11 \mathrm{C}^{+} \mathrm{CD} 103^{+} \mathrm{MHC}$ class $\mathrm{II}^{+}$DCs with classic DC function was previously described. ${ }^{36,37}$ The distinct subpopulation of gastric $\mathrm{CD}_{11} \mathrm{C}^{\text {int }} \mathrm{CD} 103^{+} \mathrm{DCs}$ in the $\mathrm{CCR} 7^{-1-}$ mice differs from those intestinal $\mathrm{CD} 11 \mathrm{C}^{+} \mathrm{CD} 103^{+} \mathrm{MHC}$ class $\mathrm{II}^{+} \mathrm{DC}$ with regard to their lower $\mathrm{CD} 11 \mathrm{C}$ and variable $\mathrm{MHC}$ class II expression levels. Hence, this gastric DC cell subpopulation most likely represents an immature DC subtype and might not serve classic DC function. CD11c intermediate expressing DCs have also been described in lungs infected with Mycobacterium tuberculosis ${ }^{38}$ and recently in murine Listeriosis. ${ }^{39}$ The authors demonstrated that these CD11c int DCs are critical for the recruitment of both $\mathrm{T}$ cell and myeloid cell migration to the lung ${ }^{38}$ and that they possessed T-cell-priming abilities. ${ }^{39}$ We hypothesize that gastric $\mathrm{CD} 11 \mathrm{C}^{\text {int }} \mathrm{CD}_{103^{+}} \mathrm{MHC}$ class IIvariable DCs support the recruitment of autoreactive $T$ cells toward and within the TLOs of $\mathrm{CCR} 7^{-1-}$ mice and might also support induction and maintenance of gastric TLO formation.

However, because of ineffective DC depletion the question of whether interaction of mature and potentially autoreactive $T$ cells with DCs is crucial for the initial development and maintenance of gastric TLOs cannot be definitely answered. Taken together, we suggest that during autoimmune inflammation autoreactive $\mathrm{CD}^{+}{ }^{+} \mathrm{T}$ cells mediate TLO development in GM tissue, most likely in cooperation with local DCs, macrophages, and B cells.

Strikingly, manifestation of AIG clearly preceded the development of TLO formation in $\mathrm{CCR} 7^{-1-}$ mice. Thus, the central question arises of whether autoreactive lymphocytes must be structurally organized to initiate disease pathogenesis.

In all other animal models of AIG, the generation of gastric antigen-specific $\mathrm{CD} 4^{+} \mathrm{T}$ cells is pivotal for the pathology. Furthermore, mononuclear infiltrates within the GM, loss of parietal and zymogenic cells, and the production of parietal cell autoantibodies are indicative of gastric autoimmunity. ${ }^{11}$ We showed that activated and putatively autoreactive $\mathrm{CD} 4^{+} \mathrm{T}$ cells act as crucial effectors and mediators in the development of $\mathrm{AIG}$ in $\mathrm{CCR} 7^{-1-}$ mice. Accordingly, we suggest that the autoreactive $\mathrm{CD}^{+} \mathrm{T}$ cells mediate the formation of an inflammatory gastric milieu characterized by the production of proinflammatory cytokines and adhesion molecules. Notably, we found enhanced gastric expression of the inflammatory cytokine IL- $1 \beta$ in CCR7 ${ }^{-1-}$ mice. This result provides a mechanistic link to the development of gastric atrophy, including parietal cell loss and metaplasia in $\mathrm{CCR} 7^{-1-}$ mice. In a recent study, an intimate relationship between acid secretion and expression of the gastric morphogenic factor Shh was shown, and it was suggested that IL-1 $\beta$ promotes Helicobacter pylori-induced gastric atrophy through suppression of Shh. ${ }^{24}$ Reduced expression of Shh by parietal cells together with increased expression of transcriptional activators of intestinal and pancreatic differentiation (ie, CDX2 and PDX1) could also lead to gastric atrophy and metaplasia. ${ }^{40}$ Here, we show that the mechanism by which IL-1 $\beta$ induces gastric atrophy during $H$. pylori-induced gastritis also applies to AIG. We envisage that loss of parietal cells in $\mathrm{CCR} 7^{-1-}$ mice is linked to the down-regulation of Shh through an IL-1 $\beta$ mediated and acid-dependent mechanism.

Impaired function or removal of $\mathrm{CD} 4^{+} \mathrm{CD} 25^{+}$Tregs can also initiate AIG. In a lymphopenic model of AIG induced by neonatal thymectomy, AIG is mainly caused by extirpation of Tregs through prevention of their export from the thymus. ${ }^{11}$ In CCR $7^{-1-}$ mice, naturally occurring Tregs develop normally in the thymus, and their in vitro suppressive activity is unhampered, whereas their suppressive function in vivo is severely impaired. ${ }^{18}$ This functional impairment is mainly due to the inability of CCR7deficient Tregs to home to the T-cell zone of LNs, where Tregs proliferate and expand on contact with their cognate antigen. In accordance, we detected numerous Tregs within loose gastric lymphoid aggregates and in structured TLOs of CCR7 ${ }^{-1-}$ mice. However, their suppressive activity might be impaired due to the inability of CCR7 ${ }^{-1-}$ Tregs to recirculate properly through tissueassociated LNs, which could explain why AIG evolves in the presence of numerous Tregs.

To investigate whether activation of autoreactive $T$ cells can occur in the GM without structured TLOs and in the absence of classic LNs, we generated CCR $7^{-1-} \mathrm{LT} \alpha^{-1-}$ double knockout mice. Despite the absence of all LNs, PPs, and structured gastric TLOs, these mice spontaneously developed severe AIG, comparable to CCR7 single knockout mice. In contrast, former studies in aly/aly mice, which completely lack LNs and PPs, suggested that cellmediated immunity, including autoimmune responses, cannot be initiated in the absence of LNs. ${ }^{41}$ This view 
was challenged by a recent study showing that aly/aly mice, which had been reconstituted with Wt hematopoietic cells and were additionally splenectomized, developed pathogenic T-cell responses. ${ }^{42}$ In agreement, initiation of cellular T-cell responses to neoantigens and autoantigens was seen in $\mathrm{Lt} \beta \mathrm{R}^{-1-}$ and $\mathrm{Lt} \alpha^{-/-}$mice strains that lack all peripheral LNs. ${ }^{41,43}$ Although we have not yet investigated the spleen as an effector site for AIG development in the $\mathrm{CCR}^{-1-} \mathrm{LT} \alpha^{-1-}$ mice, previous data of splenectomized $\mathrm{Lt} \alpha^{-/-}$and $\mathrm{Lt} \beta \mathrm{R}^{-1-}$ mice suggested that the spleen, PPs, and LNs are not absolutely required for the development of gastrointestinal immune responses. Instead, other tissues, including parenchymal organs, can develop into alternative sites of antigen processing and presentation. ${ }^{41}$

Taken together, we define the observed pathomorphologic phenotype in $\mathrm{CCR}^{-1-}$ mice as an autoimmune disease that results in atrophic gastritis. We show that immunopathogenetic steps that lead to spontaneous AIG can proceed at sites that are separate from classic LNs and organized TLOs.

\section{Acknowledgments}

We thank Kerstin Krüger, Katrin Räbel, Kerstin Gerlach, and Heike Schwede for excellent technical assistance and Christoph Loddenkemper for pathohistologic evaluation and helpful discussions.

\section{References}

1. Kim HJ, Berek C: $B$ cells in rheumatoid arthritis. Arthritis Res 2000 , 2:126-131

2. Barone $F$, Bombardieri M, Rosado MM, Morgan PR, Challacombe SJ, De Vita S, Carsetti R, Spencer J, Valesini G, Pitzalis C: CXCL13. CCL21, and CXCL12 expression in salivary glands of patients with Sjögren's syndrome and MALT lymphoma: association with reactive and malignant areas of lymphoid organization. J Immunol 2008, 180: $5130-5140$

3. Wu Q, Salomon B, Chen M, Wang Y, Hoffman LM, Bluestone JA, Fu $Y X:$ Reversal of spontaneous autoimmune insulitis in nonobese diabetic mice by soluble lymphotoxin receptor. J Exp Med 2001, 193: 1327-1332

4. Kendall PL, Yu G, Woodward EJ, Thomas JW: Tertiary lymphoid structures in the pancreas promote selection of B lymphocytes in autoimmune diabetes. J Immunol 2007, 178:5643-5651

5. Katakai T, Hara T, Sugai M, Gonda H, Shimizu A: Th1-biased tertiary lymphoid tissue supported by CXC chemokine ligand 13-producing stromal network in chronic lesions of autoimmune gastritis. J Immunol 2003, 171:4359-4368

6. Drayton DL, Liao S, Mounzer RH, Ruddle NH: Lymphoid organ development: from ontogeny to neogenesis. Nat Immunol 2006, 7:344-353

7. Carragher DM, Rangel-Moreno J, Randall TD: Ectopic lymphoid tissues and local immunity. Semin Immunol 2008, 20:26-42

8. Katakai T, Shimizu A: Undesired meeting of lymphocytes: organspecific infiltration and the organization of ectopic lymphoid tissue in a murine experimental autoimmune gastritis. Immunol Lett 2008, 118 : 103-109

9. Henry RA, Kendall PL: CXCL13 blockade disrupts B lymphocyte organization in tertiary lymphoid structures without altering B cell receptor bias or preventing diabetes in nonobese diabetic mice. $J$ Immunol 185:1460-1465

10. van Driel IR, Baxter AG, Laurie KL, Zwar TD, La Gruta NL, Judd LM, Scarff KL, Silveira PA, Gleeson PA: Immunopathogenesis, loss of $T$ cell tolerance and genetics of autoimmune gastritis. Autoimmun Rev 2002, 1:290-297

11. Field J, Biondo MA, Murphy K, Alderuccio F, Toh BH: Experimental autoimmune gastritis: mouse models of human organ-specific autoimmune disease. Int Rev Immunol 2005, 24:93-110

12. Alderuccio F, Toh BH: Spontaneous autoimmune gastritis in $\mathrm{C} 3 \mathrm{H} / \mathrm{He}$ mice: a new mouse model for gastric autoimmunity. Am J Pathol 1998, 153:1311-1318

13. Forster R, Schubel A, Breitfeld D, Kremmer E, Renner-Muller I, Wolf E, Lipp M: CCR7 coordinates the primary immune response by establishing functional microenvironments in secondary lymphoid organs. Cell 1999, 99:23-33

14. Hopken UE, Droese J, Li JP, Joergensen J, Breitfeld D, Zerwes HG, Lipp M: The chemokine receptor CCR7 controls lymph node-dependent cytotoxic T cell priming in alloimmune responses. Eur $\mathrm{J}$ Immunol 2004, 34:461-470

15. Debes GF, Arnold CN, Young AJ, Krautwald S, Lipp M, Hay JB, Butcher EC: Chemokine receptor CCR7 required for T lymphocyte exit from peripheral tissues. Nat Immunol 2005, 6:889-894

16. Hopken UE, Wengner AM, Loddenkemper C, Stein H, Heimesaat MM, Rehm A, Lipp M: CCR7 deficiency causes ectopic lymphoid neogenesis and disturbed mucosal tissue integrity. Blood 2007, 109: 886-895

17. Davalos-Misslitz AC, Rieckenberg J, Willenzon S, Worbs T, Kremmer E, Bernhardt G, Forster R: Generalized multi-organ autoimmunity in CCR7-deficient mice. Eur J Immunol 2007, 37:613-622

18. Forster R, Davalos-Misslitz AC, Rot A: CCR7 and its ligands: balancing immunity and tolerance. Nat Rev Immunol 2008, 8:362-371

19. De Togni P, Goellner J, Ruddle NH, Streeter PR, Fick A, Mariathasan S, Smith SC, Carlson R, Shornick LP, Strauss-Schoenberger, et al.: Abnormal development of peripheral lymphoid organs in mice deficient in lymphotoxin. Science 1994, 264:703-707

20. Hochweller K, Striegler J, Hammerling GJ, Garbi N: A novel CD11c.DTR transgenic mouse for depletion of dendritic cells reveals their requirement for homeostatic proliferation of natural killer cells. Eur J Immunol 2008, 38:2776-2783

21. van den Brink GR, Hardwick JC, Nielsen C, Xu C, ten Kate FJ, Glickman J, van Deventer SJ, Roberts DJ, Peppelenbosch MP: Sonic hedgehog expression correlates with fundic gland differentiation in the adult gastrointestinal tract. Gut 2002, 51:628-633

22. van den Brink GR, Hardwick JC, Tytgat GN, Brink MA, Ten Kate FJ, Van Deventer SJ, Peppelenbosch MP: Sonic hedgehog regulates gastric gland morphogenesis in man and mouse. Gastroenterology 2001, 121:317-328

23. Xiao C, Ogle SA, Schumacher MA, Orr-Asman MA, Miller ML, Lertkowit N, Varro A, Hollande F, Zavros Y: Loss of parietal cell expression of Sonic hedgehog induces hypergastrinemia and hyperproliferation of surface mucous cells. Gastroenterology 2010, 138:550$561,561 . e 551-558$

24. Waghray M, Zavros Y, Saqui-Salces M, El-Zaatari M, Alamelumangapuram CB, Todisco A, Eaton KA, Merchant JL: Interleukin-1beta promotes gastric atrophy through suppression of Sonic Hedgehog. Gastroenterology 2010, 138:562-572, 572.e561-562

25. Marshall AC, Alderuccio F, Murphy K, Toh BH: Mechanisms of gastric mucosal cell loss in autoimmune gastritis. Int Rev Immunol 2005 24:123-134

26. van Driel IR, Read S, Zwar TD, Gleeson PA: Shaping the T cell repertoire to a bona fide autoantigen: lessons from autoimmune gastritis. Curr Opin Immunol 2005, 17:570-576

27. Izcue A, Coombes JL, Powrie F: Regulatory lymphocytes and intestinal inflammation. Annu Rev Immunol 2009, 27:313-338

28. Muller G, Lipp M: Concerted action of the chemokine and lymphotoxin system in secondary lymphoid-organ development. Curr Opin Immunol 2003, 15:217-224

29. Ware CF: Network communications: Iymphotoxins. LIGHT, and TNF. Annu Rev Immunol 2005, 23:787-819

30. Kim MY, Kim KS, McConnell F, Lane P: Lymphoid tissue inducer cells: architects of CD4 immune responses in mice and men. Clin Exp Immunol 2009, 157:20-26

31. Meier D, Bornmann C, Chappaz S, Schmutz S, Otten LA, Ceredig R, Acha-Orbea H, Finke D: Ectopic lymphoid-organ development occurs through interleukin 7-mediated enhanced survival of lymphoidtissue-inducer cells. Immunity 2007, 26:643-654 
32. Lochner M, Ohnmacht C, Presley L, Bruhns P, Si-Tahar M, Sawa S, Eberl G: Microbiota-induced tertiary lymphoid tissues aggravate inflammatory disease in the absence of RORgamma t and LTi cells. $J$ Exp Med 208:125-134

33. Marinkovic T, Garin A, Yokota Y, Fu YX, Ruddle NH, Furtado GC, Lira $\mathrm{SA}$ : Interaction of mature CD3+CD4+ T cells with dendritic cells triggers the development of tertiary lymphoid structures in the thyroid. J Clin Invest 2006, 116:2622-2632

34. Hopken UE, Winter S, Achtman AH, Kruger K, Lipp M: CCR7 regulates lymphocyte egress and recirculation through body cavities J Leukoc Biol 87:671-682

35. GeurtsvanKessel CH, Willart MA, Bergen IM, van Rijt LS, Muskens F, Elewaut D, Osterhaus AD, Hendriks R, Rimmelzwaan GF, Lambrecht BN: Dendritic cells are crucial for maintenance of tertiary lymphoid structures in the lung of influenza virus-infected mice. J Exp Med 2009, 206:2339-2349

36. Schulz O, Jaensson E, Persson EK, Liu X, Worbs T, Agace WW, Pabst O: Intestinal CD103+, but not CX3CR1+, antigen sampling cells migrate in lymph and serve classical dendritic cell functions. J Exp Med 2009, 206:3101-3114

37. Jaensson $E$, Uronen-Hansson $H$, Pabst O, Eksteen B, Tian J, Coombes JL, Berg PL, Davidsson T, Powrie F, Johansson-Lindbom B, Agace WW: Small intestinal CD103+ dendritic cells display unique functional properties that are conserved between mice and humans. J Exp Med 2008, 205:2139-2149

38. Peters W, Cyster JG, Mack M, Schlondorff D, Wolf AJ, Ernst JD, Charo IF: CCR2-dependent trafficking of F4/80dim macrophages and CD11cdim/intermediate dendritic cells is crucial for T cell recruitment to lungs infected with Mycobacterium tuberculosis. J Immunol 2004 , 172:7647-7653

39. Dresing P, Borkens S, Kocur M, Kropp S, Scheu S: A fluorescence reporter model defines "Tip-DCs" as the cellular source of interferon beta in murine listeriosis. PLoS One 5:e15567

40. Faller $\mathrm{G}$, Kirchner T: Immunological and morphogenic basis of gastric mucosa atrophy and metaplasia. Virchows Arch 2005, 446:1-9

41. Hofmann J, Greter M, Du Pasquier L, Becher B: B-cells need a proper house, whereas T-cells are happy in a cave: the dependence of lymphocytes on secondary lymphoid tissues during evolution. Trends Immunol 31:144-153

42. Greter M, Hofmann J, Becher B: Neo-lymphoid aggregates in the adult liver can initiate potent cell-mediated immunity. PLoS Biol 2009, 7:e1000109

43. Lund FE, Partida-Sanchez S, Lee BO, Kusser KL, Hartson L, Hogan RJ, Woodland DL, Randall TD: Lymphotoxin-alpha-deficient mice make delayed, but effective. $T$ and $B$ cell responses to influenza. J Immunol 2002, 169:5236-5243 